\title{
Cognitive Apprenticeship Learning Approach in K-8 Writing Instruction: A Case Study
}

\author{
Nancy Akhavan ${ }^{1} \&$ Nichole Walsh ${ }^{1}$ \\ ${ }^{1}$ Department of Educational Leadership, Kremen School of Education and Human Development, California State \\ University, Fresno, CA, USA
}

Correspondence: Nichole Walsh, Kremen School of Education and Human Development M/S 305, Fresno, CA, 93740-8025, USA. E-mail: nwalsh@mail.fresnostate.edu

\author{
Received: April 20, 2020 Accepted: May 20, 2020 Online Published: May 28, 2020 \\ doi:10.5539/jel.v9n3p123 URL: https://doi.org/10.5539/jel.v9n3p123
}

\begin{abstract}
This article explains a mixed methods study utilizing multiple cases in which answers to the question of how cognitive learning theory can influence instruction that maintains the central role that teachers have in the classroom, responding to students' learning needs as they work on authentic tasks. The researcher investigated the responses of teachers to training around a model of instruction incorporating cognitive learning theory. What emerged from the inquiry was a model of instruction based on cognitive apprenticeship titled Cognitive Apprenticeship Learning Approach (CALA). This paper outlines the analysis of CALA based on the fidelity of teachers implementing carefully constructed instruction to apprentice students in writing based on teacher observations and data on student writing after attending targeted professional development. The data were collected from a group of 132 classroom teachers spanning the grades of transitional kindergarten through eighth grade. One consistent finding is that instruction based on a lesson design that focuses on cognitive apprenticeship increases students' ability to write in the early grades. The cross-case analysis revealed that teachers wanted to collaborate with peers or a coach so that it would be easier to write the lessons, and they would know which lessons were stronger than others. The analysis also revealed that teachers felt the CALA training increased their ability to teach writing and that their students' writing had improved overall.
\end{abstract}

Keywords: cognitive apprenticeship, writing instruction, cognitive learning theory, multiple case analysis, teacher professional development

\section{Introduction}

Although most agree that teaching students to write effectively is important, writing instruction has received less instructional focus than other subjects such as reading and mathematics over time (e.g., Baker, Gersten, \& Graham, 2003; Baker, Ketterlin-Gelller, Chard, Apichatabutra, \& Doabler, 2009). A more recent study of third and fourth grade teachers across the U.S. reported spending only 15 minutes a day teaching writing and only 25 minutes a day incorporating writing in other ways (Brindle, Graham, Harris, \& Hebert, 2016). This lack of focus on writing instruction occurs, in part, because teachers are inundated with "covering" standards often planned as isolated lessons leaving little to no time for explicit writing instruction (Marzano, Warrick, \& Simms, 2013; Schmoker, 2018b). Students are then taught varied or fragmented writing skills throughout the day, but regular sustained and cohesive generative writing instruction is necessary for long-term student success in literacy (Graham \& Harris, 1997; Conley, 2008; Tyre, 2012; Stuart, Jr., 2018, 2019).

More recent data confirms these conclusions in regard to a lack of attention to writing instruction. According to the National Assessment of Educational Progress (NAEP), the majority of U.S. students are not effective writers (NAEP, n.d.). On the NAEP writing assessment for $2011,80 \%$ of students in grade 8 scored at or above the basic level. While this seems to be a large number of students performing well in writing, it is essential to put the results into perspective. Basic is a "...partial mastery of prerequisite knowledge and skills that are fundamental for proficient work at each grade" (Institute of Education Sciences, n.d.).

Furthermore, students who are historically underserved-students of color and students living in poverty-the results are especially bleak. The data indicate that $89 \%$ of Black students and $85 \%$ of Hispanic students scored at basic or below. In contrast, only $13 \%$ of White students scored below basic, and $87 \%$ scored at basic and above. For students eligible for free and reduced lunch through the National School Lunch Program, 32\% scored below 
basic whereas of the group students who did not qualify for the program only $10 \%$ scored below basic.

Three writing performance areas measured on the 2011 NAEP were based on the framework guidelines. Students wrote to persuade, to explain, or to convey an experience, either real or imagined (National Assessment Governing Board, 2010). Based on the previously noted results, students lack key skills, across genres, in writing (NAEP, 2011). Additionally, "the design of the 2011 NAEP Writing Assessment reflects the way today's students compose - and are expected to compose - particularly as they move into various postsecondary settings. The assessment is designed to measure the ability of students at grades 8 and 12 to write using word processing software with commonly available tools" (National Assessment Governing Board, 2010, p. 6). Because of this critical shift to the use of computer-based technology (CBT), NCES conducted a comparative study for grade 8 students between traditional paper-pencil and CBT. They found that regardless of assessment modality, the results maintained the same stark findings (Institute of Education Sciences, n.d.).

These results are not due to a lack of scholarship. Over the past three decades, there has been a considerable amount of research about writing and cognitive processes (Anderson, Raphael, Englert, \& Stevens, 1991; Baker, Ketterlin-Gellier, Chard, Apichatabutra, \& Doabler, 2009; Graham \& Harris, 2013; Harris, Santangelo, \& Graham, 2010; Arnold, Umanath, Thio, Reilly, McDaniel, \& Marsh, 2017; Hodges, 2017). While such extensive scholarship has increased our understanding of students' writing development in schools, this body of research lacks attention to the level of congruence between planned instruction and enacted instruction, particularly in writing instruction, where the gap in achievement persists. This type of research is rooted in the belief that teachers are a vital part of the student learning process; thus, it can be grounded in the idea of cognitive apprenticeship (Collins, Brown, \& Newman, 1988).

Cognitive apprenticeship, as one instructional solution to this epidemic, focuses on explicit writing instruction to solve real-world problems (Brown, Collins, \& Duguid, 1989); thus, writing to persuade, to explain and to convey experiences are authentic, real-world problems that students work on both collaboratively and individually, both pencil-paper and through the use of CBT. The role of the teacher is critical to address student needs, as a teacher can model and coach students through writing instruction in a way that a computer-based program alone cannot (Brown, Collins, \& Duguid, 1989; Dennen \& Burner, 2008). Moreover, as teacher efficacy grows their ability to work students in this way, there can also be an impact on student learning (Klassen et al., 2011).

\subsection{Purpose of the Study}

This article presents a mixed-methods study utilizing multiple cases to explore the influence of one cognitive learning approach on writing instruction. What emerged from the inquiry was a model of instruction entitled Cognitive Apprenticeship Learning Approach (CALA). This paper outlines the analysis of CALA based on the fidelity of teachers implementing carefully constructed instruction to apprentice students in writing based on teacher observations and data on student writing after attending targeted professional development. The paper presents data analyzed at the classroom level and combines descriptions of teachers' planning and observed student writing ability through scored samples.

Attention is paid to CALA implementation because previous research indicates that the level of teachers' use of new instructional models, particularly after more than 14 hours of direct teacher professional development, significantly and positively affects student achievement (Anderson, Raphael, Englert, \& Stevens, 1991; Yoon, Duncan, Lee, Scarloss, \& Shapely, 2007). As previously established, highly needed in the area of writing instruction. Professional development on a focused, sustained topic supported by expert in-classroom coaching based on individual teacher needs and feedback - all attributes of CALA - are also found to increase the effectiveness in teacher implementation and, in turn, student performance (Darling-Hammond, Hyler, \& Gardner, 2017). Furthermore, teacher efficacy can be increased in sustained models of professional development (Ross \& Bruce, 2007; Tschannen-Moran \& McMaster, 2009), particularly when coaching is included in the first year of implementation (Ross, 1992; Shidler, 2009).

\subsection{Research Questions}

In order to understand the influence of CALA and how the results were achieved, it was important to understand how teachers perceived and performed the steps in the instructional model and how student writing ability was connected to teachers' level of implementation. This study addresses three questions:

1) Within a group of teachers who received training, what number of teachers implemented the approach with exactitude and to what level?

2) How did the level of exactitude of implementation affect students' ability to write independently immediately after a lesson? 
3) How does teachers' exactitude of implementation relate to their enacted beliefs about a change of instructional practice?

\section{Materials Studied}

Based on an integrated review, this section presents the related literature on writing instruction, mainly focused on the variables of the teacher's role in the process and how this selected role and the writing instructional strategies used impact student success. Next, based on a theoretical review, the emergence and development of Cognitive Apprenticeship are outlined, followed by a review of literature connecting teacher use of scaffolding during writing instruction to the theoretical framework. A brief description of the study context is provided in the final subsection to demonstrate the connection to the related literature and the theoretical framework.

\subsection{Review of Related Literature}

Often, in traditional U.S. public schools, writing instruction is either omitted, fragmented, or merely assigned. Experts contend that with the daunting number of content standards across the subject areas, incorporation of writing instruction is viewed as being too time-intensive, and, thus, avoided in unit planning or simply just assigned a project without explicit instruction of writing (Marzano, Warrick, \& Simms, 2013; Schmoker, 2018a). Additionally, research shows that writing instruction, to be successful, should be incorporated daily and for sustained periods; more purposeful, directed writing opportunities increase students' success as writers (e.g., Arnold et al., 2017; Hodges, 2017). Unfortunately, research finds school writing time, when planned, consists of teachers leading students through process writing without directive assistance, clear expectations, or development grit through extended writing tasks that require critical thinking, problem-solving, and elaboration beyond short responses and a focus on foundational language conventions (Graham \& Harris, 1997; Conley, 2008; Tyre, 2012; Stuart, Jr., 2018, 2019). Furthermore, writing instruction, when left to computer-based programs alone, loses the imperative social interaction required for developing skilled writers and limits feedback to basic mechanics of writing (Stevenson \& Phakiti, 2014; Stevenson, 2016). Technology should be used as a tool to enhance and support learning as preparation for future literacy contexts, not as a replacement for the teacher, including feedback with engaging dialogue around deeper concepts and critical thinking (Hunsigner-Hoft, 2016; Stevenson, 2016; Drossel, Eickelmann, \& Gerick, 2017) required of high-level writing (Tyre, 2012; Stuart, Jr., 2018, 2019). Furthermore, the integration of mobile devices as tools for student learning remains centered on teacher attitudes, beliefs, and sense of efficacy more than the tool itself (Papadakis, 2019; Kalogiannakis \& Papadakis, 2019).

Instead, to support success in writing, teachers should provide explicit instruction on the writer's craft (Graham, 2006; Graham \& Harris, 2003; Graham, Heibert, \& Harris, 2015; Graham, Harris, \& McKeown, 2014) followed by a gradual release to independence (Fisher \& Fry, 2003; Fisher \& Frey, 2013). Framing writing instruction in cognitive learning theory is one way to provide this model of explicit instruction followed by intuitive, sustained practice and feedback. Cognitive learning theory postulates that writing is constructed as a mode of communication with planning, generating, and reviewing writing at the center of the work with the teacher coming alongside the student as a coach (Mayer, 1998).

\subsection{Theoretical Framework—Cognitive Apprenticeship}

Cognitive apprenticeship is anchored in cognitive theory. Cognitive theory has impacted beliefs about teachers and learning and shaped how we understand a novice learns from an expert (Gick \& Holyoak, 1987). Cognitive apprenticeship incorporates a realistic presentation of knowledge, a procedure to apply the knowledge, and the students support during practice of these procedures and skills through coaching from the teacher (Duncan, 1996).

Cognitive apprenticeship immerses students in authentic activities in the classroom-that is, activities rooted in the disciplinary practices of historians, scientists, storytellers, journalists, and mathematicians, for example, not of "education" (Brown, Collins, \& Duguid, 1989). When students work on an authentic task, like composing their writing based on a disciplinary context, the activity of writing alongside academic interactions in the classroom regarding the writing task embeds the needed skills of critical inquiry, increased rigor, and organized thought processes (Fisher, Frey, \& Hattie, 2017). Cognitive apprenticeship is about teaching and learning through these authentic tasks and how teachers can support learning interactively.

To do this, teachers using cognitive apprenticeship intentionally make thinking visible to the learner so that the learner may own the task, strategy or skill more rapidly and effectively (Collins, Brown, \& Newman, 1988; Brown, Collins, \& Duguid, 1989; Collins et al., 1989; Collins, Brown, \& Holum, 1991). Students are challenged with tasks slightly more difficult than what they can do on their own and rely on collaborative interactions and feedback from the teacher and peers, all aspects of cognitive theory (Brown, Collins, \& Duguid, 1989; Dennen \& Burner, 2008; Duran \& Topping, 2017). Thus, students are not passive observers. While parts of cognitive apprenticeship may 
look like direct instruction followed by releasing students to complete the task assigned, the difference is in the purposeful implementation of modeling and guidance through teacher coaching and peer collaboration so that students can practice the skills and strategies to increase independence (Brown, Collins, \& Duguid, 1989; Collins et al., 1989; Collins, Brown, \& Holum, 1991; Dennen \& Burner, 2008). Through coaching, the teacher provides immediate and precise corrective feedback, which Hattie (2009) found is a high-impact learning strategy. After considerable coaching, the teacher empowers the student to continue the task with peer engagement as needed, or practice independently (Brown, Collins, \& Duguid, 1989). The teacher then moves to a facilitative role, observing the students while they work, scaffolding as necessary to help students as they practice.

\subsection{Scaffolding to Advance Students' Writing Abilities}

Teacher modeling increases students' ability to write, but more effective in literacy instruction is providing scaffolds for students to use when writing independently (Fisher, Frey, \& Hattie, 2017). Scaffolds are temporary supports that a teacher offers a student so that they can write their own thoughts and ideas, rather than copy teacher or class produced writing. Scaffolds "provide just enough support to students so [students] can make progress or carry out writing tasks, but encourage [students] to act in a self-regulated fashion, doing as much as they can on their own" (Graham \& Harris, 2019, p. 14). Cognitive apprenticeship can be used to help students become strategic writers of their thoughts and ideas (Duncan, 1996), which becomes more effective through the intentional incorporation of scaffolds (Fisher, Frey, \& Hattie, 2017).

\subsection{Importance of Metacognition in Writing}

As they write, students also need to engage their metacognition (Mayer, 1998). As students develop an awareness of what the teacher is modeling about writing, they can think for themselves about their performance during and after the writing task. Explicit attention to the mental processes that advance writing and having opportunities to talk with expert and novice writers can increase students' ability to write (Anderson, Raphael, Englert, \& Stevens, 1991). Making thinking visible is a crucial step in cognitive apprenticeship, as previously outlined, and is found to be another high impact strategy on increasing student achievement (Hattie, 2009), specifically one to accelerate learning in literacy development (Fisher, Frey, \& Hattie, 2017) which includes writing instruction (Harris, Santangelo, \& Graham, 2010).

\subsection{Description of Study Context}

This study included professional development and observation of student work. Cognitive theory was reflected in professional development training provided to teachers in multiple districts over 12 years. Cognitive Apprenticeship Learning Approach (CALA) includes six critical elements: (1) direct explanation of the information, strategy or skill to be learned; (2) modeling of the use of the information, strategy or skill through teacher action and thinking aloud about the cognitive processes used by the teacher to complete the task at hand: (3) scaffolding provided by the teacher to support the students in working through the task, skill or strategy on their own, this includes the teacher modeling using the scaffold; (4) the teacher checking for understanding and engagement of students with the intent and how-to of the task, skills or strategy before releasing the student to practice on their own or collaboratively; (5) coaching of students while they are practicing to provide immediate feedback on how they are doing and helping students reflect on what is working or not working during the completion of the task; (6) whole-group reflection and articulation by students so students can share what they worked on, what occurred while they were working and what they think about their work with the task, skill or strategy. The study was conducted with archived data collected from professional development training.

\section{Methods}

This study is based on an existing document collection of training rosters and agendas, artifacts from training including the researcher's field notes, lesson plans written by teachers who experienced the training, observations of instruction of teachers who received training and student writing samples from the teachers' classrooms who had attended the training. The document collection occurred between 2002 and 2019. Data were not collected consecutively during these years. Data were collected between 2002 and 2007 and from 2012 to 2019 .

\subsection{Sample}

The information was collected from a group of 132 classroom teachers spanning the grades of transitional kindergarten through eighth grade with 124 hired as "regular" classroom teachers and eight as "resource" classroom teachers. Resource classroom teachers provide instruction tailored for students who require additional instruction for learning. In the first three years, data were collected from 18 teachers: 2003 to 2006, 16 teachers; 2013 to 2014, 17 teachers; 2014, 12 teachers; 2015 to 2016, 23 teachers; and, 2017 to 2019, 85 teachers (See Table 1). All of the teachers had voluntarily participated in a four-day training writing training with participation 
encouraged by principals and district literacy administrators. The school districts were located in the Western U.S., and, with the exception of one school district, the schools were located in suburban areas with ethnically-mixed populations with over one-half the population receiving free and reduced lunch from the National School Lunch Program.

Table 1. Participant overview

\begin{tabular}{llll}
\hline Year(s) & District & School & Number of Teachers Involved \\
\hline $2017-2019$ & I & A & 25 \\
2019 & I & C & 17 \\
2019 & I & F & 14 \\
$2017-2019$ & I & G & 18 \\
2015 & II & D & 13 \\
2014 & III & E & 12 \\
$2013-2014$ & III & H & 17 \\
$2003-2006$ & IV & B & 16 \\
\hline
\end{tabular}

\subsection{Staff Development Training}

The noted writing training was implemented over four days, configured differently for each of the school districts participating in the professional development. For the Districts receiving training during 2002 to 2007, and 2012 to 2013 the training was provided one day at a time over one school year, with the training ending in March. The observations occurred during the fall semester and the subsequent spring semester. For the District trained in 2014 to 2016, the four-day training occurred over the summer with follow up observations occurring in the fall semester. For the District participating from 2017 to 2019, the training occurred one day per month in the fall semester with observations also occurring during the same semester and the subsequent spring semester.

\subsubsection{Curriculum Materials}

A distinctive feature of the training was the use of a lesson planning template that teachers used to organize their instruction into six steps. Four steps occurred during a mini-lesson, and two of the steps occurred while students were writing. The six steps included 1) direct explanation, 2) modeling, 3) scaffolding, 4) checking for engagement and understanding, 5) coaching, and 6) student reflection and articulation.

The CALA model happens in phases - a mini lesson, student collaborative or independent work and student sharing about accomplishments. A lesson planning sheet cued the teachers about each step they were to either direct, coach, or guide. The lesson planning sheet was intended to be a support during early teacher implementation to ensure they were following the steps of cognitive apprenticeship during writing instruction. For example, the lesson planning sheet organized direct explanation, modeling, scaffolding and a check for engagement and understanding in a four-step minilesson, then the lesson planning sheet included a place for the teacher to organize how they would coach students during their task and facilitate student reflection and articulation after they completed the daily task. The lesson planning sheets were intended to be eliminated once teachers internalized the lesson phases. The lesson planning sheet did not differ over the years of implementation of the model. The lesson planning sheets and other elements of the training are presented in Akhavan (2007a), Akhavan (2007b), Akhavan (2014), and Akhavan (2018).

\subsubsection{Staff Development Activities}

During the four days of training, participating teachers learned to create lessons based on cognitive apprenticeship, with each step of CALA represented in the previously noted lesson planning sheets. Once teachers began instruction with CALA, they were visited by the researcher. Teachers at schools A, B, and G had the greatest number of visits, and sites D and $\mathrm{E}$ had only one visit per teacher. Schools $\mathrm{C}$ and $\mathrm{F}$ had a minimum of three visits per teacher. Schools G and H had visits to half of the teachers' classrooms. During these visits, the researcher observed the teachers, and at times, assisted the teachers by occasionally teaching lessons, modeling a step within the lesson, or coaching students on expectations. The researcher typically consulted with the teachers about their practice, concerns, and ideas about CALA as well. For schools A, B, C, D, and F group meetings were held after school at least once every other month. For schools A, B, and F group meetings were monthly or more often based on teacher requests.

While some elements of the staff development were comparable for all the teachers (training, content, and access to consultations), other elements differed depending on each districts' training schedule and teachers' desire for 
consultation. One researcher provided all the professional development, conducted observations, and provided the follow-up consultations.

\subsection{Measures}

Data reported in this article come from a variety of sources. The researcher kept field notes during trainings, observations, and consultation meetings, in addition to collecting training artifacts. Student writing samples were also collected from schools A, B, C and F. Not all schools participated in the collection of student writing samples because of the limitations set out by the principal of each school, or a district administrator.

\subsubsection{Artifacts}

Training artifacts included lesson plans, posters, and other planning materials shared with the researcher by the teachers. These were one of the primary data sources analyzed for the first research question.

\subsubsection{Observations}

Observations during training and classroom visits were the secondary data analyzed to answer research questions one and three. There were two types of observations: formal and informal. The observations were conducted using a checklist based on the lesson template. Formal observations were conducted at schools A, B, C, and F. School E only participated in informal observations due to the parameters that the District placed on the research. The formal observations were conducted during a one-hour observation of a writing lesson. During observations, the researcher was strictly an observer and did not play any other role in the classroom. The researcher took anecdotal field notes and used an observation checklist to document the actions teachers took during each part of the CALA lesson.

Informal observations were not as systematic. The researcher took descriptive notes on what was seen during the lesson, also noting the teaching tools (e.g., anchor charts and writing models) used during each step of the CALA lesson. The informal observations were conducted in all districts and each teacher had a minimum of one informal observation. These observations occurred when the researcher visited the classrooms of teachers who had participated in training. All informal observations occurred prior to formal observations. During informal observations, the researcher, as needed, played an active role in the classroom; thus, some informal observation notes were taken immediately following the lesson.

\subsubsection{Student Writing Samples}

The researcher collected student writing samples as evidence of CALA implementation. The writing samples indicated the quality of the direct explanation and the amount of scaffolding the teacher provided as well as the coaching the teacher provided while students were writing from the formal observations. The writing samples were not analyzed for overall quality of writing but for evidence of student learning from the specific skill associated with the mini-lesson, and teacher support during student coaching. Three student writing samples were collected for each formal observation. The writing samples were collected from students whom the teacher identified as high-ability, expected-ability, and lower-than-expected-ability based on the respective lesson. The samples were examined in connection to the teachers' lesson plans and the observation notes from each formal observation.

The writing samples included various genres - narrative, opinion/argument or report. The writing from the lessons required students to either share an experience, real or imagined, write information about something that they had been studying, or write an opinion or argument. The narrative task expected them to organize a story by the beginning, middle, and end and include characters and dialogue through a remembered or fictional event. The opinion/argument (depending on grade-level standards) genre expected students to use information from a studied topic and make a claim with supporting textual evidence. The report task expected students to write about a topic that the class had researched or that they had researched themselves. If the students were in kindergarten, first and second grade, the students wrote about a topic that the class had studied together. Students in grades third through eighth wrote about a topic that they had researched on their own with appropriate developmental scaffolds, such as graphic organizers, to collect and note needed information for their writing.

\subsubsection{Field Notes}

Field notes from training and informal classroom observations provided clarity on the collected training artifacts and the informal observation notes. The researcher kept field notes during the training. During breaks, when participants were completing collaborative activities, or immediately after the session, the researcher recorded significant moments during the training and what participants had shared. Additionally, the researcher kept notes during the informal observations along with anecdotal notes from the lesson events, which resulted in eight handwritten notebooks. The researcher used the field notes to provide additional detail in understanding the 
training agendas, participants' reactions to training activities, and information about the students when they were writing. Additionally, the researcher noted personal reflections regarding the training and the lesson implementation during observations.

\subsection{Participant Bias}

This study used existing data from professional development programs for teachers. Participant bias could have played a factor in the implementation of CALA in order to be seen favorably by administration. To mitigate this bias, and increase the authenticity of teachers' ability to learn and try new instructional methods, the researcher developed rapport built on confidentiality with each teacher participant as the professional development provider.

\subsection{Observer Bias}

The downside of personal knowledge of a particular participant group is the potential for researcher bias. However, personal knowledge can also provide theoretical sensitivity. Strauss and Corbin (1998) define sensitivity as "having insight into, and being able to give meaning to, the events and happenings in data" (p. 46). Sensitivity is a quality that helps a researcher to recognize what may be important in the data. Sensitivity also aids the researcher in identifying inconsistencies between an individual's behavior and standard practice. In this case, the initial theoretical sensitivity was brought to the situation through the researcher's professional experience and research interests. The researcher has worked as a member of a district leadership team, as a school leader in several school districts. This researcher has operational knowledge concerning how, where, and why teachers implement change in their classrooms.

\section{Results}

The types of training that teachers attended was slightly different based on how the training was provided over the number of days, and the researcher did discuss teachers' use of the training in follow up meetings in their classrooms during informal observations and during formal follow-up meetings in order to increase the effectiveness of the teachers' implementation of the program.

\subsection{Scoring Procedures for Lesson Plans}

In order to develop a score for understanding teachers' degree of congruence with the researcher's idea of implementation, the researcher looked at lesson plans that the teachers wrote during professional development training and the notes from the observations. Three lesson plans for each teacher were scored. The lesson plans were analyzed using a rating scale that the researcher had created. The researcher assigned a scaled score for each teacher based on the lesson plans and training field notes.

Based on the steps in the CALA lesson, the researcher developed a four-point scale to be rated from 0 to 3 , with the following meanings regarding the researcher's expectation of CALA lesson planning: $0=$ no attempt; $1=$ attempt nearly matched; 2 = attempt mostly matched, and; 3 = attempt matched to a high degree. The researcher was looking for the following criteria in the planning of the CALA lesson:

1) Mini-lesson and Writing Task: Lesson plan included a mini-lesson followed by a writing task and time for reflection and articulation.

2) Structure of Mini-lesson: Mini-lesson plan had four parts including a connection, direct instruction including, modeling and scaffolding, engagement, and check for understanding and closure.

3) Writing After a Lesson: Teacher planned to release the students to a writing task, either independent or collaborative.

4) Writing Task Organization: Writing task was collaborative or independent writing, not copied writing, and students would be supported to write on their own, using learning tools from the scaffolding presented in the lesson.

5) Final Reflection and Articulation: Following the writing task, the teacher planned to facilitate five to ten minutes of discussion during which students would reflect on their writing and articulate their thinking and shared writing. The lesson plan indicated support to ensure the reflection and articulation would occur.

Table 2 presents descriptive data for 132 participating teachers in regards to lesson planning scores after training. The results indicate an overall lesson planning mean of $2.39(\mathrm{~N}=139, \mathrm{SD}=.84)$, meaning lesson planning attempts mostly matched the researcher expectations after the CALA training.

A one-way ANOVA was conducted, and no significant difference $(F(9,123)=1.237, p=.279)$ between grade levels of participating teachers was found (see Table 3 ). These results were expected as all teachers attended the same training over four days with a focus on developing lesson plans utilizing a common template. 
Table 2. Means and standard deviations for lesson plan scores by grade level

\begin{tabular}{llll}
\hline Grade & M & SD & N \\
\hline No Grade & 2.04 & 1.02 & 25 \\
K & 2.27 & 1.01 & 11 \\
1 & 2.27 & .96 & 15 \\
2 & 2.79 & .43 & 14 \\
3 & 2.57 & .65 & 14 \\
4 & 2.55 & .68 & 11 \\
5 & 2.33 & .98 & 12 \\
6 & 2.73 & .65 & 11 \\
7 & 2.38 & .52 & 8 \\
8 & 2.27 & .90 & 11 \\
Total & $\mathbf{2 . 3 9}$ & $\mathbf{. 8 4}$ & $\mathbf{1 3 2}$ \\
\hline
\end{tabular}

Table 3. Summary table for the one-way ANOVA using lesson plan scores as the dependent variable and grade level as the independent variable

\begin{tabular}{llllll}
\hline Source & Sum of Squares & df & Mean Square & F & p \\
\hline Between Groups & 7.80 & 9 & .867 & 1.237 & .279 \\
Within Groups & 85.49 & 123 & .701 & & \\
Total & $\mathbf{9 3 . 2 9}$ & $\mathbf{1 3 2}$ & & & \\
\hline
\end{tabular}

\subsection{Scoring Procedures for Teacher Observations}

Because it was essential to understand the enacted action of the teacher, and not just the plan, the observation was scored, comparing the level of implementation with the researcher's idea of implementation. The researcher scored the lesson based on the anecdotal notes from the observations and used the field notes to corroborate any confusing points. The researcher developed a four-point scale to rate the degree in which the planned lesson was taught $(1$, no attempt; 2 , nearly matched; 3 , mostly matched; and, 4 , matched to a high degree). The researcher looked for the following actions during CALA lesson observations:

1) Implementation of Mini-lesson: Teacher taught a mini-lesson which had four parts including a connection, direct instruction including modeling and scaffolding, engagement and check for understanding and closure. The teacher provided direct explanation and modeling. The lesson included a scaffold the students could use while writing on their own.

2) Implementation of Writing After Lesson: Teacher facilitated students to work on an independent or collaborative writing task. Students used independent ideas rather than copied the teacher's model. The teacher coached the students during the writing task, providing immediate corrective feedback to the students about their writing and reminded them to use the scaffolds from the lesson.

3) Implementation of Final Reflection and Articulation: Following the writing task, the teacher facilitated five to ten minutes of discussion during which students reflected on their writing and articulated their thinking and shared writing.

Table 4 presents descriptive data on scoring of 118 teacher observations. The results indicate an overall lesson planning mean of $2.13(\mathrm{~N}=118, \mathrm{SD}=.81)$, indicating that the teachers' implementation of their lesson plans nearly matched the observation indicators. The primary grade teachers' scores had higher means indicating that these teachers were closer to implementing CALA well.

Table 4. Means and standard deviations for teacher observation scores by grade level

\begin{tabular}{llll}
\hline Grade & M & SD & N \\
\hline No Grade & 1.52 & .51 & 25 \\
K & 2.50 & .97 & 10 \\
1 & 2.46 & .78 & 13 \\
2 & 2.83 & .39 & 12 \\
3 & 2.42 & .67 & 12 \\
4 & 2.22 & .44 & 9 \\
5 & 2.20 & .63 & 10 \\
6 & 1.90 & .99 & 10 \\
7 & 1.86 & .69 & 7 \\
8 & 1.90 & 1.10 & 10 \\
Total & $\mathbf{2 . 1 3}$ & $\mathbf{. 8 1}$ & $\mathbf{1 1 8}$ \\
\hline
\end{tabular}


A one-way ANOVA was run, and there was a significant difference $(F(9,109)=4.412, p<.001)$ in the implementation of CALA between grade levels observations, See Table 5. With no significant difference across grade levels for lesson planning, the significant difference of observation scores was not expected as the teachers had access to the developed plan while teaching.

A post hoc test revealed significant differences between those teaching Grade 2 and No Grade Indicated $(M$ dif $=$ $1.313, \mathrm{p}<.001)$, between those teaching Grade 1 and No Grade Indicated $(M \operatorname{dif}=.942, \mathrm{p}=.008)$, and between those teaching Grade $\mathrm{K}$ and No Grade Indicated $(M$ dif $=.980, \mathrm{p}=.015)$ The adjusted $R^{2}$ for this model is $20.8 \%$. However, with the least amount of observed implementation attributed to teachers in grades 4 through 8 , qualitative data were used to inform this phenomenon which is reported in respective subsequent sections.

Table 5. Summary table for the one-way ANOVA using teacher observation scores as the dependent variable and grade level as the independent variable

\begin{tabular}{llllll}
\hline Source & Sum of Squares & df & Mean Square & F & p \\
\hline Between Groups & 20.73 & 9 & 2.30 & 4.412 & $<.001$ \\
Within Groups & 56.37 & 109 & .52 & & \\
Total & $\mathbf{7 7 . 1 0}$ & $\mathbf{1 1 8}$ & & & \\
\hline
\end{tabular}

\subsection{Scoring Procedures for Student Writing Samples}

Seeing a lesson implemented and scoring that lesson against the predetermined criteria did not provide an assessment of student learning from the lesson. In order to understand what students were able to do based on the lesson, student work samples from the lesson were evaluated. First, the researcher examined writing samples from the lesson from all students in the class and took notes in the field journal on the overall match between the student writing and the lesson objective. A set of a priori codes organized the notes from the field journal in order to code the field note data. The following descriptors were used to code the data:

1) Student writing mostly did not match the lesson objective: For nearly all the students in the class, their writing, written during a 20-30-minute designated writing time, did not match the lesson objective or stem from the lesson delivery and scaffolding provided. Most students' writing was on another topic or a few students did not write.

2) Student writing mostly matched the lesson objective: For most of the students in the class, their writing, written during a 20-30-minute designated writing time, did match the lesson objective or stem from the lesson delivery and scaffolding provided. Some students' writing was on another topic or a few students did not write.

3) Student writing matched the lesson objective: For nearly all the students in the class, their writing, written during a 20-30-minute designated writing time, did match the lesson objective or stem from the lesson delivery and scaffolding provided. A small number (one to two) of students' writing was on another topic. All students wrote.

Additionally, the researcher collected three student work samples from the lesson. The researcher chose student work samples that represented students in the class who easily completed the task, who seemed to be working for more time on the task, and students who struggled with the task. One piece of student writing was collected from a student who completed the task and had a formative piece of writing that matched the objective, from one student who had written the task, but the writing was not completed, or only matched the task slightly, and one from a student who appeared to struggle with the task as there was very little writing or the writing did not match the task. The field note codes from the student work samples and the ratings of the student work samples were evaluated for alignment using a 4-point scale (1, no alignment; 2, some alignment with many mechanical errors; 3, alignment with few mechanical errors; and, 4, strong alignment with little to no mechanical errors).

Table 6 presents descriptive data of the scoring for 107 student writing samples. Writing samples were not collected from all of the classroom observations. Writing samples were omitted from the observations of teachers in districts that did not approve the collection of student writing. The results indicate an overall student work sample mean of $2.15(\mathrm{~N}=107, \mathrm{SD}=.84)$, meaning students were able to write based on the taught objective in the lesson plans, but that there were some errors in the writing. The means for writing samples collected from primary grades had slightly higher means indicating a greater match between the writing and the lesson objective. 
Table 6. Means and standard deviations for student work sample scores by grade level

\begin{tabular}{llll}
\hline Grade & M & SD & N \\
\hline No Grade & -- & -- & -- \\
K & 2.45 & 1.04 & 11 \\
1 & 2.47 & .83 & 15 \\
2 & 2.57 & .76 & 14 \\
3 & 2.29 & .73 & 14 \\
4 & 1.73 & .65 & 11 \\
5 & 1.83 & .83 & 12 \\
6 & 2.09 & .70 & 11 \\
7 & 1.63 & .74 & 8 \\
8 & 1.91 & .94 & 11 \\
Total & $\mathbf{2 . 1 5}$ & $\mathbf{. 8 4}$ & $\mathbf{1 0 7}$ \\
\hline
\end{tabular}

A one-way ANOVA was run, and the data indicate a significant difference $(F(8,99)=2.157, p=.037)$ in the quality of the work samples in between grades (see Table 7). This finding, in the context of the previous result showing significantly differing observed lessons across grade levels, were expected, particularly in grades 4 through 8 , where lesson observation mean scores were low. If the observed lesson did not have as much alignment to the planned lesson, it is expected the students would perform at a lower level in relation to the writing task.

Table 7. Summary table for the one-way ANOVA using student work sample scores as the eependent variable and grade level as the independent variable

\begin{tabular}{llllll}
\hline Source & Sum of Squares & df & Mean Square & F & p \\
\hline Between Groups & 11.32 & 8 & 1.42 & 2.157 & .037 \\
Within Groups & 64.29 & 99 & .52 & & \\
Total & $\mathbf{7 5 . 6 1}$ & $\mathbf{1 0 7}$ & & & \\
\hline
\end{tabular}

\subsection{Exactitude as the Relationship Between Teacher Congruence and Student Writing as Implementation Evidence}

In order to analyze the overall CALA implementation by teachers, the respective students' scores on the writing samples were compared to the teachers' congruence with the work. First, the determination of congruence is explained and the results presented. Then, the comparison of these scores to the student work samples are presented and analyzed for overall implementation and by grade level.

\subsubsection{Determination of Congruence from Teacher Performance Data Averages}

The congruence score is used as a measure of teachers' CALA implementation in practice. To find this score, first the data from the analysis of lesson plans were averaged with the data from observations. Only those pairwise data sets with both an observation and a lesson plan score were included in the analyses. The resulting score $(2.40, \mathrm{~N}=$ 93) indicates teachers are moving beyond attempted implementation for the congruence between the lesson plan and observations within the CALA model. Table 8, below, provides the descriptives for congruence scores.

Table 8. Means and standard deviations for overall congruence of lesson plan and observation scores by grade level

\begin{tabular}{llll}
\hline Grade & M & SD & N \\
\hline $\mathrm{K}$ & 2.45 & .93 & 10 \\
1 & 2.38 & .77 & 13 \\
2 & 2.88 & .31 & 12 \\
3 & 2.54 & .58 & 12 \\
4 & 2.44 & .39 & 9 \\
5 & 2.30 & .79 & 10 \\
6 & 2.30 & .67 & 10 \\
7 & 2.07 & .53 & 7 \\
8 & 2.05 & .96 & 10 \\
Total & $\mathbf{2 . 4 0}$ & $\mathbf{. 7 0 4}$ & $\mathbf{9 3}$ \\
Grade & $\mathbf{M}$ & SD & $\mathbf{N}$ \\
\hline
\end{tabular}


Comparison of congruence across grade levels indicate, again, that while overall congruence is moving from attempted to strong levels of implementation, teachers in second grade had the highest level of congruence $(\mathrm{M}=$ $2.88)$ and those in grades seventh $(\mathrm{M}=2.07)$ and eighth $(\mathrm{M}=2.05)$ had the lowest. Further observation shows a downward trend in congruence levels after second grade; however, most notable from teachers in grade four $(\mathrm{M}=$ 2.44) to grade five $(M=2.30)$ and again from grades six $(M=2.30)$ to seven $(M=2.07)$. In the context of the previous findings, these results are not surprising; however, the qualitative data were used to understand this phenomenon, which is reported in respective subsequent sections.

\subsubsection{Analysis of Exactitude}

To analyze the exactitude of CALA teacher implementation, the relationship between the congruence and the student writing sample scores were found. Only participant data, which included a congruence score and a paired student writing sample score, were included in this analysis with $\mathrm{N}=93$. Means and standard deviations for the student in each group are given in Table 9.

Table 9. Means and standard deviations for overall congruence and student writing scores by grade level for exactitude analysis

\begin{tabular}{llllll}
\hline \multirow{2}{*}{$\begin{array}{l}\text { Variable } \\
\text { Grade }\end{array}$} & Congruence & \multicolumn{2}{l}{ Student Writing } & N \\
\cline { 2 - 5 } & $\mathrm{M}$ & $\mathrm{SD}$ & $\mathrm{M}$ & $\mathrm{SD}$ & \\
\hline $\mathrm{K}$ & 2.45 & .93 & 2.60 & .97 & 10 \\
1 & 2.38 & .77 & 2.54 & .78 & 13 \\
$\mathbf{2}$ & $\mathbf{2 . 8 8}$ & $\mathbf{. 3 1}$ & $\mathbf{2 . 8 3}$ & $\mathbf{. 3 9}$ & $\mathbf{1 2}$ \\
3 & 2.54 & .58 & 2.42 & .67 & 12 \\
4 & 2.44 & .39 & 1.89 & .60 & 9 \\
5 & 2.30 & .79 & 2.00 & .82 & 10 \\
6 & 2.30 & .67 & 2.10 & .74 & 10 \\
7 & 2.07 & .53 & 1.57 & .79 & 7 \\
8 & 2.05 & .96 & 1.90 & .94 & 10 \\
Total & $\mathbf{2 . 4 0}$ & $\mathbf{. 7 0 4}$ & $\mathbf{2 . 2 6}$ & $\mathbf{. 8 2 0}$ & $\mathbf{9 3}$ \\
\hline
\end{tabular}

The most exactitude is observed in second grade, where congruence $(\mathrm{M}=2.88)$ and student writing scores $(2.83)$ are almost aligned. In grades $\mathrm{K}$ and one, it is observed that student work scores are higher than teacher congruence. Starting in grade three, the opposite trend is observed - mean congruence is higher than mean student work scores. As previously data indicate similar findings, this again was expected but required further analysis using qualitative data to understand and interpret.

\subsection{Analysis of Enacted Teacher Belief Data}

The data presented for understanding teachers' exactitude of implementation of CALA did not provide information regarding their enacted beliefs about the approach. In order to understand how teachers' beliefs were enacted in their classrooms, a multiple case study was completed. To create the cases the data sources used included the researcher's field notes from training and observations, the checklists from observations, field notes from the trainings, the notes from the examination of student work, and the score from the teacher performance data. The data were used to construct narratives in an attempt to show how teacher beliefs were enacted in the classroom. The cases were scripted per a structured format. Developing "a descriptive framework for organizing the case study" (Yin, 1994, p. 114) is most applicable to exploratory research.

\subsubsection{Multiple Case Analysis}

In order to determine replication feasibility in the multiple case examination, a replication strategy was implemented. Yin (1994) compares the use of a replication strategy for conducting a number of separate studies on related topics. The strategy in this study was to look for data trends across all data district by district so that saturation in the findings would occur across Districts, not within districts data. So, one teacher was examined from one District, then another teacher from another District, and so on until saturation of information occurred, and the themes in the data began repeating. First, literal replication was identified in the cases. Cases were identified across Districts that were similar to one another. Next theoretical replication was conducted to explore trends further and confirm or disprove patterns found in the cases. Eisenhardt (1989) points out that if all or most cases produce similar results, there can be substantial support for the development of a theory.

The cases are a representative sample of all the teachers involved in the CALA training who had student work 
examined. In order to have representation across all the Districts, the cases were spread out across the district as evenly as possible based on the replication strategy. Saturation occurred after 15 cases. The selection also included balance in teacher exactitude in implementation, with at least one teacher selected to be from a high accuracy between implementation and intent of CALA, there was also an effort to have equal numbers of medium accuracy between implementation and intent and teachers considered to have low accuracy between implementation and intent. In the sample, eight teachers were considered to have high accuracy, six with medium accuracy, and four with low accuracy.

In order to draw conclusions and specify patterns, the teachers in a manner that allowed for comparison for a within-case analysis, a review was completed on all the artifacts from training labeled with teachers' names, field notes, checklists, and student work. Summaries were written using a standard outline, which included information gathered from the walls of the classroom during the observations, lesson observations, examination of student work, examination of lesson plans, and discussions with the teacher during training, informal observations, and other meetings. Not all teachers interacted with the researcher to the same degree so there were not detailed notes from every teacher. The researcher developed the cases with the information available. The format for each of the cases begins with an introduction to the teacher. Next, the summary included is the length of training the teacher participated in and details about the teacher's impressions of student learning. The accuracy of CALA was discussed, and details from lessons, classroom walls, and student work were written into the summary. Anecdotes unique to each teacher were written into the summaries. Refer to Appendix (Table 11) for a summary tabulation of the cases by District.

\subsubsection{Cross-Case Analysis}

Following the within-case analysis, an analysis was conducted across the cases, referred to as a cross-case analysis (Cresswell, 1998). Inductive analysis was conducted for the cross-case analysis. Emerging codes from all cases suggested categories that could form themes and synthesis of information across the cases (Miles \& Huberman, 1994). The main approach to this step involved detailed analysis and coding of one case from each school district. Then the second case was coded with the same themes. If new themes were identified, the first case was re-coded. This process continued with all cases until themes that cut across all cases were identified.

A master display matrix was created containing all the final themes in the form of columns, and each case was represented in the form of rows. A matrix pulled together all the themes in columns and their representative findings from each District in rows. The themes from each District related to the mini-lessons, student practice with writing, teacher collaboration, and teacher efficacy. A summary tabulation of themes by District appears in Table 10. Axial coding was conducted to combine the themes in the matrix into overarching theme descriptions. The final themes were as follows: 1) collaborative planning led to more student writing practice; 2) teacher modeling affected student learning in the CALA model; 3) teacher efficacy grew during the CALA training and implementation; and, 4) teachers needed support to not be overwhelmed by the change in instruction.

Table 10. Cross-case analysis themes by District

\begin{tabular}{|c|c|c|c|c|}
\hline District & Theme 1 & Theme 2 & Theme 3 & Theme 4 \\
\hline I & $\begin{array}{l}\text { Mini-lessons guide } \\
\text { learning because of } \\
\text { showing how to write } \\
\text { through modeling }\end{array}$ & $\begin{array}{l}\text { Teachers need support to } \\
\text { change instruction }\end{array}$ & $\begin{array}{l}\text { Keeping up with writing, posting, } \\
\text { correcting, revising and grading } \\
\text { was time-consuming and } \\
\text { overwhelming }\end{array}$ & $\begin{array}{l}\text { Teachers felt op about their } \\
\text { ability to impact student } \\
\text { writing }\end{array}$ \\
\hline II & $\begin{array}{l}\text { Student learning } \\
\text { depended on teacher } \\
\text { modeling }\end{array}$ & $\begin{array}{l}\text { The lesson planning with } \\
\text { colleagues was key to } \\
\text { good lessons }\end{array}$ & $\begin{array}{l}\text { Coaching and collaboration led to } \\
\text { better planning }\end{array}$ & $\begin{array}{l}\text { Teachers enjoyed teaching } \\
\text { writing and felt positive about } \\
\text { student learning }\end{array}$ \\
\hline III & $\begin{array}{l}\text { Shortened instructional } \\
\text { time through } \\
\text { mini-lessons (avoiding } \\
\text { lecture) led to more } \\
\text { student practice }\end{array}$ & $\begin{array}{l}\text { Collaboration amongst } \\
\text { grade level teachers led to } \\
\text { better minilessons }\end{array}$ & Not evident & $\begin{array}{l}\text { Teachers felt positive about } \\
\text { the amount of writing students } \\
\text { were doing and the quality of } \\
\text { the writing }\end{array}$ \\
\hline IV & $\begin{array}{l}\text { Student learning in } \\
\text { writing is based on } \\
\text { teacher modeling and } \\
\text { thinking aloud }\end{array}$ & $\begin{array}{l}\text { Teacher efficacy grew } \\
\text { from collaborating about } \\
\text { writing lessons }\end{array}$ & $\begin{array}{l}\text { Teachers did not feel they could } \\
\text { judge the quality of student } \\
\text { writing on their own }\end{array}$ & $\begin{array}{l}\text { Units of study filled with } \\
\text { purposeful mini lessons were } \\
\text { empowering }\end{array}$ \\
\hline $\begin{array}{l}\text { Cross- } \\
\text { Case }\end{array}$ & $\begin{array}{l}\text { Collaborative planning } \\
\text { led to more student } \\
\text { writing practice }\end{array}$ & $\begin{array}{l}\text { Teacher modeling } \\
\text { affected student learning } \\
\text { in the CALA model }\end{array}$ & $\begin{array}{l}\text { Teacher efficacy grew during the } \\
\text { CALA training and } \\
\text { implementation }\end{array}$ & $\begin{array}{l}\text { Teachers needed ongoing } \\
\text { support to not be overwhelmed } \\
\text { by the change in instruction }\end{array}$ \\
\hline
\end{tabular}


The findings of the cross-case analysis indicate that teacher efficacy grows as teachers work collaboratively together, and when their efficacy in teaching writing increased, students tended to write more often. For teachers with high and medium levels of congruence between their practice, the CALA model provided more opportunities for students to write regularly, which, in turn, provided students with more writing practice. One teacher with high congruence (District IV, school B) noted that, "students showed the most significant growth in report writing and persuasive writing." As teachers' efficacy grew during CALA training and implementation, those teachers who implemented with higher levels of congruence saw greater impact on their learning and student learning. Teachers in District I felt positive about their ability to impact students' writing with one teacher stating, "students had grown tremendously in their ability to write during science and to write reports." Teachers with low levels of congruence, though still implementing CALA, had less efficacy, and their students demonstrated less success in writing ability. For example, one teacher with lower congruence noted, "I saw some students writing more, but overall, not a lot of writing was completed by students."

Another theme was related to teacher feelings of overwhelm. Support, through collaborative planning, in-classroom observation, and overall encouragement during training, were influential in guiding teachers' ability to manage the change related to their writing instruction. These findings indicate that teachers need support while implementing a new type of instruction. They also need leaders to create opportunities for teacher collaboration with each other and perhaps with an instructional coach in order to focus on planning. Through collaboration, teachers expressed that they felt stronger about being able to write lessons that would have a good effect on student learning after they taught it. The cross-case analysis also revealed that teachers felt the CALA training increased their ability to teach writing and that their students' writing had improved overall. The cognitive apprenticeship model guided the teachers through their instruction, and the teachers noted that this increased their feelings of efficacy. They felt that what they were doing mattered for students, and they felt empowered by being able to make decisions on which writing lessons to teach and use a model that released responsibility to the students gradually.

\section{Discussion}

In general, results suggest that the CALA approach with writing is effective. One consistent finding is that a lesson design focused on cognitive apprenticeship increases students' ability to write in the early grades. The more aligned the teacher was in delivering instruction to the planned lesson, with four parts including direct explanation, modeling, engagement, and closure, the closer students' writing was to the expected writing outcome. Overall, primary grade teachers (grades K-2) were implementing the model to a higher level than teachers in grades $3-8$. It was not that the teachers in grades 3-8 were not using the model, it is just that the teachers in grades 3-8 were not using the model to its fullest degree. Observations showed that these teachers were implementing their lessons, but that they were taking longer and modeling less, providing less time for students to see how the teachers were translating their thinking into writing. One possible reason for the downward trend in teacher congruence is that the modeling expected in the CALA lesson is more similar to what early grade teachers do routinely. The upper-grade teachers were learning to model and be more specific in their instructional expectations, and while this still led to student learning, the teachers were not as exact in their implementation of the model.

The less that teachers provided direct explanation and modeling through a mini-lesson, and the less teachers coached when the students were writing, the weaker the student writing became. As Brown, Collins and Duguid (1989) acknowledged, cognitive apprenticeship is about students working on authentic tasks with an understanding based on the teacher's modeling. Immediate feedback is a part of cognitive apprenticeship. The findings show that increased feedback changed the students' ability to write aligned to the teaching objective. It could be speculated that the more teachers engaged with students to think about their writing meta-cognitively, and act on their own, the better the students' writing became.

As Graham and Harris (1997, 2013, 2019) note in their research, school writing time, when planned, consists of small amounts of directive assistance, clear expectations, and development of perseverance through extended writing tasks that require high order thinking. These findings were also noted in the current study, when teachers spent time on planning writing lessons to guide students, not just to assign writing, and modeled during their lessons, students' ability to write increased. The teachers in the CALA training planned for the systematic implementation of writing focused first on the content (as in a narrative or report) and then later the mechanics of writing. These findings support Graham and Harris' $(1997,2013,2019)$ model of writing.

Another set of findings suggests that teachers needed collaborative time to plan. The cross-case analysis revealed that teachers wanted to collaborate with peers or a coach so that it would be easier to write the lessons, and they would know which lessons were stronger than others. Increased coaching through sustained models of professional development reinforced existing literature regarding increasing teachers' ability to implement new 
instruction (Ross, 1992; Ross \& Bruce, 2007; Shidler, 2009; Tschannen-Moran \& McMaster, 2009). Therefore, this study adds to the existing research on the importance of professional development to increase teacher efficacy.

\subsection{Implications for Practice}

First, for school and District leaders, this study supports professional development for teachers of a cognitive approach to writing instruction with six steps: four steps occurring during a mini-lesson and two steps occurring while students are writing. The outcome, an approach titled Cognitive Apprenticeship Learning Approach (CALA), provides an exemplar of theory to practice, where changes in instruction to affect student learning are the goal. The current study also provides a template for writing instruction and professional development to support the teachers' learning of the cognitive learning approach. The instructional strategies provide evidence for conducting instruction with small amounts of directive assistance, clear expectations, and the development of perseverance through extended writing tasks (Graham \& Harris, 2013). This research can also help school leaders as often teachers turn in lesson plans or spend time with colleagues planning, but the outcomes of the planning do not always translate into taught instruction. Understanding the connection between planned instruction and enacted instruction, as seen in this study through the examination of levels of congruence, can provide school leaders insight into the support they may need to provide to their teachers to help them enact the lessons they work so hard to develop.

The results of this study also support the ways that professional development can increase teacher self-efficacy (Tschannen-Moran \& McMaster, 2009) as teachers noted that they felt supported by the professional development providers, and this increased their ability to use the CALA model to teach writing. Follow up coaching during professional development had significant positive results, as discussed by Tschannen-Moran and McMaster (2009). The findings in this study were similar; this has implications for school and district leaders as they design professional development and consider follow-up coaching.

This study adds to the literature in the area of writing instruction and provides an instructional model that teachers can follow. University programs that provide in-service learning opportunities for teachers and classes for pre-service teachers could use the findings of the study to implement the six-step writing instructional model. The key to the findings was the teacher modeling for students to understand how to write. University faculty could discuss the purpose and productivity of modeling on student learning and help both in-service and pre-service teachers hone their skills of modeling during their lessons.

\subsection{Implications for Future Research}

Based on this study, there are several additional implications for future research. First, the study was based on an existing document collection; this study should be replicated in a school setting where the researcher can conduct observations in one or more schools while conducting the training and providing the professional development support. Also, longitudinal studies of a multi-year implementation of the professional development need to be conducted to understand change over time with teachers' efficacy and exactitude to the CALA model beyond the first year of training. In what ways would teacher efficacy change, and how would teachers perceive the CALA model after more than one year of implementation? How would students' ability to write change as teachers gained experience and confidence in delivering well-planned lessons where they coached students to improve their writing?

In the current study that focused on the fidelity of teachers implementing carefully constructed instruction based on cognitive apprenticeship, the thoughts and opinions of students about writing instruction was not examined. Implementation of student focus-group interviews could give insight into what parts of the instruction and feedback helped students learn at higher levels. An understanding of the types of modeling and instructional support could be developed by talking with students.

The question of why student writing ability did not increase at the same rate that teachers implemented the writing approach with fidelity could also be explored. In this study, it was noted that upper-grade teachers were learning new techniques with instruction overall; however, the student writing was not meeting the expectations of the teacher based on the lessons. An in-depth analysis of the type of modeling done by teachers in the lessons and the ways that teachers give feedback to students to improve their writing ability could be examined through observations in classrooms for multiple sessions over many months.

\section{Conclusion}

The findings indicate that CALA is an effective model of instruction and can be used in classrooms to promote student learning. This study adds to the existing research examining cognitive instructional approaches and teacher efficacy as in this study results indicate that teachers' felt more efficacious as they used the CALA model, and 
through collaboration and support their lessons were more congruent with the model. As the literature indicates when teachers teach writing by focusing on some direct explanation with ample feedback, student writing ability increases (Graham \& Harris, 2013). CALA employs a similar lesson design. This study provides new insight to the existing research on the importance of small amounts of assisted instruction, including modeling, followed by feedback. Based on the findings, subsequent iterations of CALA professional development will include increased support for teachers in lesson planning and the implementation of modeling during instruction. A higher congruence between the planned lesson and the taught lesson will improve student learning in writing in grades three through eighth grade. Additionally, student writing will be examined in alignment with lessons across a unit to see to what degree the student writing abilities change over the progression of a unit. The CALA training will continue to support teachers to use cognitive apprenticeship in writing to move students gradually from direct explanation and modeling to independent abilities.

\section{References}

Anderson, L. M., Raphael, T. E., Englert, C. S., \& Stevens, D. D. (1991). Teaching writing with a new instructional model: Variations in teachers' beliefs, instructional practice, and their students' performance. Research Series 209, Institute for Research on Teaching, Michigan State University. Retrieved from https://https://files.eric.ed.gov/fulltext/ED341994.pdf

Arnold, K. M., Umanath, S., Thio, K., Reilly, W. B., McDaniel, M. A., \& Marsh, E. J. (2017). Understanding the cognitive processes involved in writing to learn. Journal of Experimental Psychology, 23(2), 115-127. https://doi.org/10.1037/xap0000119

Baker, S., Gersten, R., \& Graham, S. (2003). Teaching expressive writing to students with learning disabilities: research-based applications and examples. Journal of Learning Disabilities, 36(2), 109-123. https://doi.org/10.1177/002221940303600204

Baker, S. K., Chard, D. J., Ketterlin-Geller, L. R., Apichatabutra, C., \& Doabler, C. (2009). Teaching Writing to At-Risk Students: The Quality of Evidence for Self-Regulated Strategy Development. Exceptional Children, 75(3), 303-318. https://doi.org/10.1177/001440290907500303

Brindle, M., Graham, S., Harris, K. R., \& Hebert, M. (2016). Third and fourth grade teacher's classroom practices in writing: a national survey. Reading and Writing, 29, 929-954. https://doi.org/10.1007/s11145-015-9604-x

Brown, J. S., Collins, A., \& Duguid, P. (1989). Situated cognition and the culture of learning. Educational Researcher, 18(1), 32-42. https://doi.org/10.3102/0013189X018001032

Collins, A., Brown, J. S., \& Holum, A. (1991). Cognitive apprenticeship: Making thinking visible. American Educator. American Federation of Teachers. Retrieved from https://eric.ed.gov/?id=EJ440511

Collins, A., Brown, J. S., \& Newman, S. E. (1988). Cognitive apprenticeship: Teaching the craft of reading, writing and mathematics. Thinking: The Journal of Philosophy for Children, 8(1), 2-10. https://doi.org/10.5840/thinking 19888129

Conley, D. T. (2008). College knowledge: What it really takes for students to succeed and what we can do to get them ready. John Wiley \& Sons.

Darling-Hammond, L., Hyler, M. E., \& Gardner, M. (2017). Effective Teacher Professional Development. Palo Alto, CA: Learning Policy Institute. Retrieved from https://learningpolicyinstitute.org/product/teacher-prof-dev

Dennen, V. P., \& Burner, K. J. (2008). The cognitive apprenticeship model in educational practice. In J. M. Spector, M. D. Merrill, J. van Merrienboer \& M. P. Driscoll (Eds.), Handbook of research on educational communications and technology (Vol. 3, pp. 425-439). New York: Taylor \& Francis Group.

Drossel, K., Eickelmann, B., \& Gerick, J. (2017). Predictors of teachers' use of ICT in school-the relevance of school characteristics, teachers' attitudes and teacher collaboration. Education and Information Technologies, 22(2), 551-573. https://doi.org/10.1007/s10639-016-9476-y

Duncan, S. L. S. (1996). Cognitive Apprenticeship in Classroom Instruction: Implications for Industrial and Technical Teacher Education. Journal of Informational Technology Education, 33(3). Retrieved from https://scholar.lib.vt.edu/ejournals/JITE/

Duran, D., \& Topping, K. (2017). Learning by Teaching: Evidence-based strategies to enhance learning in the classroom. Routledge. https://doi.org/10.4324/9781315649047

Eisenhardt, K. M. (1989). Building theories from case study research. Academy of Management Review, 14(4), 
532-550. https://doi.org/10.2307/258557

Fisher, D., \& Frey, N. (2003). Writing instruction for struggling adolescent readers: a gradual release model: because new accountability systems focus on writing, struggling students need daily, coordinated instruction that is meaningful. Journal of Adolescent \& Adult Literacy, 46(5), 396-405. Retrieved from https://www.jstor.org/stable/40017794

Fisher, D., \& Frey, N. (2013). Better Learning Through Structured Teaching: A Framework for the Gradual Release of Responsibility (2nd ed.). Alexandria, VA: ASCD.

Fisher, D., Frey, N., \& Hattie, J. (2017). Visible Learning for Literacy: Implementing the Practices That Work Best to Accelerate Student Learning. Thousand Oaks, California: Corwin, a SAGE company.

Gick, M. L., \& Holyoak, K. J. (1987). The cognitive basis of knowledge transfer. In S. M. Cormier \& J. D. Hagman (Eds.), Transfer of learning: Contemporary research and application (pp. 9-46). San Francisco: Academic Press. https://doi.org/10.1016/B978-0-12-188950-0.50008-4

Graham, S. (2006). Strategy instruction and the teaching of writing: A metaanalysis. In C. A. MacArthur, S. Graham \& J. Fitzgerald (Eds.), Handbook of writing research (pp. 187-207). New York: Guilford Press.

Graham, S., \& Harris, K. R. (1997). Self-regulation and writing: Where do we go from here? Contemporary Educational Psychology, 22(1), 102-114. https://doi.org/10.1006/ceps.1997.0920

Graham, S., \& Harris, K. R. (2003). Students with learning disabilities and the process of writing: A meta-analysis of SRSD studies. In H. L. Swanson, K. R. Harris \& S. Graham (Eds.), Handbook of learning disabilities (pp. 383-402). New York: Guilford Press.

Graham, S., \& Harris, K. R. (2013). Designing an effective writing program. In S. Graham, C. MacArthur \& J. Fitzgerald (Eds.), Best practices in writing instruction (2nd ed., pp. 3-25). NewYork: Guilford

Graham, S., \& Harris, K. R. (2019). In S. Graham, C. MacArthur \& M. Hebert (Eds.), Best Practices in Writing Instruction (3rd ed., pp. 3-28). New York: Guilford Press.

Graham, S., Harris, K. R., \& McKeown, D. (2014). The writing of students with learning disabilities, meta-analysis of self-regulated strategy development writing intervention studies, and future directions: Redux. In H. L. Swanson, K. R. Harris \& S. Graham (Eds.), Handbook of learning disabilities (pp. 405-438). New York, NY: Guilford Press.

Graham, S., Heibert, M., \& Harris, K. R. (2015). Formative assessment and writing: A meta-analysis. Elementary School Journal, 115(4), 523-547. https://doi.org/10.1086/681947

Harris, K. R., Santangelo, T., \& Graham, S. (2010). Metacognition and strategies instruction in writing. In H. S. Waters \& W. Schneider (Eds.), Metacognition, strategy use, and instruction (pp. 226-256). New York, NY: Guilford Press.

Hattie, J. (2009). Visible learning for teachers: Maximizing impact on learning. Routledge.

Hodges, T. S. (2017). Theoretically speaking: An examination of four theories and how they support writing in the classroom. The Clearing House: A Journal of Educational Strategies, Issues and Ideas, 90(4), 139-146. https://doi.org/10.1080/00098655.2017.1326228

Hunsigner-Hoft, S. (2016). Personalized learning with digital devices. Center on Innovations in Learning. Temple University, Philadelphia, PA. Retrieved http://www.centeril.org/publications/PL\%20With\%20Digital\%20Devices.pdf

Institute of Education Sciences. (n.d.). Achievement levels. Performance metrics: Overview. Retrieved from https://nces.ed.gov/nationsreportcard/ndehelp/webhelp/achievement_levels.htm

Kalogiannakis, M., \& Papadakis, S. (2019). Evaluating pre-service kindergarten teachers' intention to adopt and use tablets into teaching practice for natural sciences. International Journal of Mobile Learning and Organisation, 13(1), 113-127. https://doi.org/10.1504/IJMLO.2019.096479

Klassen, R. M., Tze, V. M. C., Betts, S. M. et al. (2011). Teacher Efficacy Research 1998-2009: Signs of Progress or Unfulfilled Promise? Educational Psychology Review, 23, 21-43. https://doi.org/10.1007/s10648-010-9141-8

Marzano, R. J., Warrick, P., \& Simms, J. A. (2013). A handbook for high reliability schools: The next step in school reform. Solution Tree.

Mayer, R. E. (1998). Cognitive theory for education: What teachers need to know. In N. M. Lambert \& B. L. 
McCombs (Eds.), How students learn: Reforming schools through learner-centered education (pp. 353-377). (Reprinted in modified form from "Journal of Educational Psychology", 84, 1992, pp. 405-412) American Psychological Association. https://doi.org/10.1037/10258-013

National Assessment Governing Board. (2010). Writing framework for the 2011 national assessment of educational progress. US Department of Education. ERIC Clearinghouse. Retrieved from https://www.nagb.gov/content/nagb/assets/documents/publications/frameworks/writing/2011-writing-frame work.pdf

Norris, C., \& Soloway, E. (2019). Personalized learning vs. social learning. The Learning Counsel: Research and context on the digital education experience. Retrieved from https://thelearningcounsel.com/article/personalized-learning-vs-social-learning

Papadakis, S. (2018). Evaluating pre-service teachers' acceptance of mobile devices with regards to their age and gender: a case study in Greece. International Journal of Mobile Learning and Organisation, 12(4), 336-352. https://doi.org/10.1504/IJMLO.2018.095130

Ross, J. A. (1992). Teacher efficacy and the effect of coaching on student achievement. Canadian Journal of Education, 17, 51-65. https://doi.org/10.2307/1495395

Ross, J., \& Bruce, C. (2007). Professional development effects on teacher efficacy: Results of randomized field trial. Journal of Educational Research, 101, 50-60. https://doi.org/10.3200/JOER.101.1.50-60

Schmoker, M. (2018a). Demystifying writing, transforming education. Educational Leadership, 75(7), 22-27. Retrieved

from https://www.studentachievement.org/wp-content/uploads/Writing-Demystifying-Writing-Transforming-Edu cation-Educational-Leadership.pdf

Schmoker, M. (2018b). Focus: Elevating the essentials to radically improve student learning. Ascd.

Shidler, L. (2009). The impact of time spent coaching for teacher efficacy on student achievement. Early Childhood Education Journal, 36(5), 453-460. https://doi.org/10.1007/s10643-008-0298-4

Stevenson, M. (2016). A critical interpretive synthesis: The integration of automated writing evaluation into classroom writing instruction. Computers and Composition, 42, 1-16. https://doi.org/10.1016/j.compcom.2016.05.001

Stevenson, M., \& Phakiti, A. (2014). The effects of computer-generated feedback on the quality of writing. Assessing Writing, 19, 51-65. https://doi.org/10.1016/j.asw.2013.11.007

Stuart, Jr., D. (2018). These 6 Things: How to Focus Your Teaching on What Matters Most. Corwin Press.

Stuart, Jr., D. (2019). Building an earnest and amicable argument culture in the Secondary classroom. Language Arts Journal of Michigan, 34(2), 10. https://doi.org/10.9707/2168-149X.2215

Tschannen-Moran, M., \& McMaster, P. (2009). Sources of self-efficacy: Four professional development formats and their relationship to self-efficacy and implementation of a new teaching strategy. Elementary School Journal, 110, 228-245. https://doi.org/10.1086/605771

Tyre, P. (2012). The writing revolution. The Atlantic, 310(3), 96-101. Retrieved from https://go-gale-com.hmlproxy.lib.csufresno.edu/ps/i.do?id=GALE\%7CA307670106\&v=2.1\&u=csufresno\& $\mathrm{it}=\mathrm{r} \& \mathrm{p}=\mathrm{PROF} \& \mathrm{sw}=\mathrm{w}$

Yin, R. K. (1994). Case study research: Design and methods. Thousand Oaks, CA: Sage.

Yoon, K. S., Duncan, T., Lee, S. W.-Y., Scarloss, B., \& Shapley, K. (2007). Reviewing the evidence on how teacher professional development affects student achievement (Issues \& Answers Report, REL 2007, No. 033). Washington, DC. Retrieved from https://ies.ed.gov/ncee/edlabs/regions/southwest/pdf/REL_2007033.pdf 


\section{Appendix A}

Table 11. Summary tabulation of the cases by district and school

\begin{tabular}{|c|c|c|c|c|c|c|}
\hline $\begin{array}{l}\text { District, } \\
\text { School }\end{array}$ & $\begin{array}{l}\text { Grade } \\
\text { levels } \\
\text { in case }\end{array}$ & $\begin{array}{l}\text { Congruence } \\
\text { between teachers' } \\
\text { implementation } \\
\text { and CALA model }\end{array}$ & $\begin{array}{l}\text { Writing Instruction During } \\
\text { CALA }\end{array}$ & $\begin{array}{l}\text { Evidence on } \\
\text { classroom walls }\end{array}$ & $\begin{array}{l}\text { Teachers } \\
\text { impression of } \\
\text { student } \\
\text { learning } \\
\end{array}$ & $\begin{array}{l}\text { General Teacher } \\
\text { comments } \\
\text { regarding CALA }\end{array}$ \\
\hline $\mathrm{I}, \mathrm{A}$ & 2 nd & High & $\begin{array}{l}\text { Focused on genre writing in } \\
\text { three genres. } \\
\text { Strong minilessons } \\
\text { implemented. Scaffolds were } \\
\text { provided to guide student } \\
\text { independent work. Unlimited } \\
\text { time and support provided for } \\
\text { students to write. Taught four } \\
\text { days per week. }\end{array}$ & $\begin{array}{l}\text { Student writing was } \\
\text { posted that indicated } \\
\text { students were able to } \\
\text { write in the genre } \\
\text { being taught. Visual } \\
\text { supports from } \\
\text { lessons were evident } \\
\text { (eg anchor charts). }\end{array}$ & $\begin{array}{l}\text { Teacher felt that } \\
\text { students were } \\
\text { able to write } \\
\text { based on her } \\
\text { minilessons. She } \\
\text { believed mini } \\
\text { lessons guided } \\
\text { learning. }\end{array}$ & $\begin{array}{l}\text { Helpful. The } \\
\text { scaffolding makes } \\
\text { sense. }\end{array}$ \\
\hline $\mathrm{I}, \mathrm{A}$ & $3 \mathrm{rd}$ & Medium & $\begin{array}{l}\text { Focused on genre writing in } \\
\text { three genres. } \\
\text { Minilessons implemented but } \\
\text { were teacher dominated and } \\
\text { did not provide student well } \\
\text { designed scaffolds. Unlimited } \\
\text { time to write. Taught three to } \\
\text { four days per week. }\end{array}$ & $\begin{array}{l}\text { Anchor charts were } \\
\text { on walls from } \\
\text { minilessons. } \\
\text { Sentence frames } \\
\text { were posted. }\end{array}$ & $\begin{array}{l}\text { Teacher felt that } \\
\text { students were } \\
\text { writing better in } \\
\text { ELA and in } \\
\text { science. }\end{array}$ & $\begin{array}{l}\text { Enjoyed the mini } \\
\text { lessons, likes how } \\
\text { the lessons break } \\
\text { down instruction } \\
\text { into supportive } \\
\text { components. }\end{array}$ \\
\hline $\mathrm{I}, \mathrm{A}$ & 8 th & High & $\begin{array}{l}\text { Focused on genre writing in } \\
\text { three genres. } \\
\text { Strong minilessons } \\
\text { implemented. Scaffolds were } \\
\text { provided to guide student } \\
\text { independent work. } 20 \\
\text { minutes provided for students } \\
\text { to write. } 15 \text { minutes share } \\
\text { time at the end of writing } \\
\text { time. Taught four days per } \\
\text { week. }\end{array}$ & $\begin{array}{l}\text { Student writing was } \\
\text { posted that indicated } \\
\text { students were able to } \\
\text { write in the genre } \\
\text { being taught. Visual } \\
\text { supports from } \\
\text { lessons were evident } \\
\text { (eg anchor charts). }\end{array}$ & $\begin{array}{l}\text { Teacher stated } \\
\text { that even the } \\
\text { most reluctant } \\
\text { learners were } \\
\text { writing. }\end{array}$ & $\begin{array}{l}\text { Teacher liked } \\
\text { using anchor } \\
\text { charts and created } \\
\text { a place in front of } \\
\text { the room where } \\
\text { charts were } \\
\text { displayed }\end{array}$ \\
\hline $\mathrm{I}, \mathrm{A}$ & 4 th & High & $\begin{array}{l}\text { Focused on genre writing in } \\
\text { three genres. } \\
\text { Strong minilessons } \\
\text { implemented. Multiple } \\
\text { scaffolds were provided to } \\
\text { guide student independent } \\
\text { work. Taught three to four } \\
\text { days per week. }\end{array}$ & $\begin{array}{l}\text { Student writing was } \\
\text { posted, the front of } \\
\text { the classroom had } \\
\text { sentence frames } \\
\text { posted. }\end{array}$ & $\begin{array}{l}\text { Teacher wanted } \\
\text { to provide } \\
\text { additional } \\
\text { practice for } \\
\text { students using } \\
\text { supports such as } \\
\text { index cards to } \\
\text { organize writing. }\end{array}$ & $\begin{array}{l}\text { Teacher stated she } \\
\text { loved the lessons } \\
\text { and felt } \\
\text { empowered. }\end{array}$ \\
\hline I, A & 7 th & Low & $\begin{array}{l}\text { Focused on genre writing in } \\
\text { one genre. } \\
\text { Minilessons of varying levels } \\
\text { of quality implemented. } \\
\text { Taught sporadically. }\end{array}$ & $\begin{array}{l}\text { Student writing was } \\
\text { not evident. A few } \\
\text { anchor charts were } \\
\text { posted on the side } \\
\text { walls. }\end{array}$ & $\begin{array}{l}\text { Teacher felt } \\
\text { frustrated with } \\
\text { students as they } \\
\text { were not writing } \\
\text { as much as she } \\
\text { wanted. }\end{array}$ & $\begin{array}{l}\text { Teacher asked for } \\
\text { additional support. }\end{array}$ \\
\hline $\mathrm{I}, \mathrm{G}$ & 4 th & High & $\begin{array}{l}\text { Focused on writing about } \\
\text { reading to reflect on reading } \\
\text { strategies. Strong mini lesson } \\
\text { to support independent } \\
\text { writing. Unlimited time to } \\
\text { write. Taught five days per } \\
\text { week. }\end{array}$ & $\begin{array}{l}\text { Student writing was } \\
\text { posted that indicated } \\
\text { students were able to } \\
\text { write in the genre } \\
\text { being taught. Visual } \\
\text { supports from } \\
\text { lessons were evident } \\
\text { (eg anchor charts). }\end{array}$ & $\begin{array}{l}\text { Teacher felt very } \\
\text { encouraged } \\
\text { about students' } \\
\text { ability to write } \\
\text { informational } \\
\text { text reports. }\end{array}$ & $\begin{array}{l}\text { Teacher liked the } \\
\text { sequence of the } \\
\text { lessons. }\end{array}$ \\
\hline $\mathrm{I}, \mathrm{G}$ & 5 th & High & $\begin{array}{l}\text { Focused on writing about } \\
\text { reading to reflect on reading } \\
\text { strategies. Extremely strong } \\
\text { mini lesson with multiple } \\
\text { scaffolds to support } \\
\text { independent writing. } \\
\text { Unlimited time to write. } \\
\text { Taught five days per week. }\end{array}$ & $\begin{array}{l}\text { Student writing was } \\
\text { posted that indicated } \\
\text { students were able to } \\
\text { write in the genre } \\
\text { being taught. } \\
\text { Abundant visual } \\
\text { supports from } \\
\text { lessons were evident } \\
\text { (e.g., anchor charts). }\end{array}$ & $\begin{array}{l}\text { Teacher wanted } \\
\text { students to write } \\
\text { more, however, } \\
\text { their writing had } \\
\text { progressed } \\
\text { significantly } \\
\text { from the } \\
\text { beginning of the } \\
\text { year. }\end{array}$ & $\begin{array}{l}\text { Teacher liked the } \\
\text { sequence of the } \\
\text { lessons and stated } \\
\text { that she could } \\
\text { grow in student } \\
\text { writing. }\end{array}$ \\
\hline
\end{tabular}




\begin{tabular}{|c|c|c|c|c|c|c|}
\hline $\mathrm{I}, \mathrm{G}$ & 7 th & Medium & $\begin{array}{l}\text { Focused on writing about } \\
\text { reading using worksheet-type } \\
\text { writing placed in a writing } \\
\text { notebook. Mini Lesson to } \\
\text { support independent writing } \\
\text { in the notebook. Unlimited } \\
\text { time to write. Taught three to } \\
\text { four days per week. }\end{array}$ & $\begin{array}{l}\text { Student writing was } \\
\text { not evident. There } \\
\text { were anchor charts } \\
\text { on the walls, but they } \\
\text { were disorganized. }\end{array}$ & $\begin{array}{l}\text { Teacher stated } \\
\text { students could } \\
\text { write in journals, } \\
\text { but did not see } \\
\text { growth in writing } \\
\text { reports or } \\
\text { narratives. }\end{array}$ & $\begin{array}{l}\text { Teacher liked the } \\
\text { lessons, she } \\
\text { requested more } \\
\text { support. }\end{array}$ \\
\hline $\mathrm{I}, \mathrm{G}$ & 7 th & Low & $\begin{array}{l}\text { Focused on writing about } \\
\text { reading in a notebook. No } \\
\text { minilesson to support } \\
\text { independent writing, only } \\
\text { explanation of direction. } \\
\text { Limited time to write and the } \\
\text { time was unfocused. Taught } \\
\text { four to five days per week. }\end{array}$ & $\begin{array}{l}\text { No student writing } \\
\text { was posted in the } \\
\text { room. There were no } \\
\text { anchor charts on the } \\
\text { walls. There were no } \\
\text { sentence frames or } \\
\text { other supports. }\end{array}$ & $\begin{array}{l}\text { Teacher stated } \\
\text { that students } \\
\text { were not writing } \\
\text { during the } \\
\text { writing block. } \\
\text { Stated that time } \\
\text { was wasted. }\end{array}$ & $\begin{array}{l}\text { Teacher stated that } \\
\text { minilessons were } \\
\text { difficult and } \\
\text { wanted support in } \\
\text { the direct } \\
\text { instruction and } \\
\text { modeling. }\end{array}$ \\
\hline IV, B & $2 \mathrm{nd}$ & High & $\begin{array}{l}\text { Focused on writing about } \\
\text { reading to reflect on reading } \\
\text { strategies. Extremely strong } \\
\text { minilessons to support } \\
\text { independent writing. } \\
\text { Scaffolds were built into the } \\
\text { lessons. Unlimited time to } \\
\text { write. Taught five days per } \\
\text { week. }\end{array}$ & $\begin{array}{l}\text { Walls provide } \\
\text { multiple scaffolds } \\
\text { for students to } \\
\text { support learning. } \\
\text { Word walls provided } \\
\text { to help with writing. } \\
\text { Several word banks } \\
\text { provided. }\end{array}$ & $\begin{array}{l}\text { Teacher was } \\
\text { very positive } \\
\text { about the } \\
\text { student's ability } \\
\text { to write and } \\
\text { stated students } \\
\text { had shown } \\
\text { tremendous } \\
\text { growth. }\end{array}$ & $\begin{array}{l}\text { Teacher was very } \\
\text { happy with the } \\
\text { model and liked } \\
\text { the units of study. }\end{array}$ \\
\hline IV, B & $1 \mathrm{st}$ & Low & $\begin{array}{l}\text { Focused on writing in three } \\
\text { genres. Weak minilessons. } \\
\text { Some scaffolds provided. } \\
\text { Coaching was provided } \\
\text { during unlimited time to } \\
\text { write. Taught four days per } \\
\text { week. }\end{array}$ & $\begin{array}{l}\text { Student writing was } \\
\text { only in the journal } \\
\text { and appeared } \\
\text { sporadically } \\
\text { throughout. }\end{array}$ & $\begin{array}{l}\text { Teacher reported } \\
\text { that she saw } \\
\text { some students } \\
\text { writing more, but } \\
\text { overall, not a lot } \\
\text { of writing. }\end{array}$ & $\begin{array}{l}\text { The teacher found } \\
\text { the minilessons } \\
\text { difficult as she had } \\
\text { trouble with the } \\
\text { modeling. }\end{array}$ \\
\hline IV, B & 6 th & High & $\begin{array}{l}\text { Focused on writing in reading } \\
\text { extensively about reading } \\
\text { comprehension as text } \\
\text { dependent writing. Large } \\
\text { number of high-quality } \\
\text { scaffolds provided. Unlimited } \\
\text { time to write. Taught four } \\
\text { days per week. notebooks. }\end{array}$ & $\begin{array}{l}\text { Student writing was } \\
\text { posted that indicated } \\
\text { students were able to } \\
\text { write in the genre } \\
\text { being taught. Visual } \\
\text { supports from } \\
\text { lessons were evident } \\
\text { on one wall in the } \\
\text { classroom (e.g., } \\
\text { anchor charts). }\end{array}$ & $\begin{array}{l}\text { Students showed } \\
\text { the most } \\
\text { significant } \\
\text { growth in report } \\
\text { writing and } \\
\text { persuasive } \\
\text { writing. }\end{array}$ & $\begin{array}{l}\text { Teacher reported } \\
\text { the best part of the } \\
\text { lesson was the } \\
\text { modeling and } \\
\text { chunking of skills. }\end{array}$ \\
\hline IV, B & $3 \mathrm{rd}$ & Medium & $\begin{array}{l}\text { Focused on writing in reading } \\
\text { about reading comprehension } \\
\text { as text dependent writing. } \\
\text { Some scaffolds provided. } \\
\text { Unlimited time to write. } \\
\text { Taught four days per week. } \\
\text { notebooks. }\end{array}$ & $\begin{array}{l}\text { Student writing was } \\
\text { posted that indicated } \\
\text { students were able to } \\
\text { write in the genre } \\
\text { being taught. Visual } \\
\text { supports from } \\
\text { lessons were evident } \\
\text { (eg anchor charts). }\end{array}$ & $\begin{array}{l}\text { Students were } \\
\text { able to write to a } \\
\text { moderate extent } \\
\text { in three genres. }\end{array}$ & $\begin{array}{l}\text { Teacher enjoyed } \\
\text { the minilessons } \\
\text { and felt the } \\
\text { breakdown of the } \\
\text { writing process } \\
\text { was helpful. }\end{array}$ \\
\hline III, H & $1 \mathrm{st}$ & Low & $\begin{array}{l}\text { Focused on writing in three } \\
\text { genres. Minilessons were } \\
\text { scattered and not well } \\
\text { organized. Limited scaffolds } \\
\text { provided. No support to } \\
\text { students while writing } \\
\text { independently. }\end{array}$ & $\begin{array}{l}\text { There was no writing } \\
\text { on the walls. The } \\
\text { walls did not support } \\
\text { writing work. There } \\
\text { was not a word wall. }\end{array}$ & $\begin{array}{l}\text { Students wrote } \\
\text { some in journals, } \\
\text { but did not write } \\
\text { to genres. }\end{array}$ & $\begin{array}{l}\text { Teacher stated that } \\
\text { focusing on the } \\
\text { objective during } \\
\text { lessons was } \\
\text { difficult. }\end{array}$ \\
\hline III, H & $2^{\text {nd }}$ & Medium & $\begin{array}{l}\text { Focused on writing about } \\
\text { reading. Minilesson } \\
\text { supported students with } \\
\text { vocabulary development. } \\
\text { Scaffolds were demonstrated. } \\
20 \text { minutes to write. Taught } \\
\text { one or two times per week. }\end{array}$ & $\begin{array}{l}\text { There was no writing } \\
\text { on the walls. The } \\
\text { walls did have } \\
\text { supportive directions } \\
\text { posted on the } \\
\text { whiteboards. }\end{array}$ & $\begin{array}{l}\text { Student writing } \\
\text { in journals was } \\
\text { increasing. }\end{array}$ & $\begin{array}{l}\text { Teacher had } \\
\text { trouble with the } \\
\text { students' } \\
\text { independent } \\
\text { writing time. She } \\
\text { wanted to control } \\
\text { more of the } \\
\text { student work time. }\end{array}$ \\
\hline III, H & 7 th & High & $\begin{array}{l}\text { Focused on genre writing in } \\
\text { three genres. }\end{array}$ & $\begin{array}{l}\text { There was student } \\
\text { writing evident on }\end{array}$ & $\begin{array}{l}\text { Teacher stated } \\
\text { that students had }\end{array}$ & $\begin{array}{l}\text { Teacher enjoyed } \\
\text { the shortness of }\end{array}$ \\
\hline
\end{tabular}




\begin{tabular}{|c|c|c|c|c|c|c|}
\hline & & & $\begin{array}{l}\text { Strong minilessons } \\
\text { implemented. Multiple } \\
\text { scaffolds were provided to } \\
\text { guide student independent } \\
\text { work. Unlimited time to } \\
\text { write. Taught three to four } \\
\text { days per week. }\end{array}$ & $\begin{array}{l}\text { the walls. There } \\
\text { were no other } \\
\text { supports posted. }\end{array}$ & $\begin{array}{l}\text { grown } \\
\text { tremendously in } \\
\text { their writing } \\
\text { ability in } \\
\text { narrative writing. }\end{array}$ & $\begin{array}{l}\text { the lessons and the } \\
\text { focus on modeling } \\
\text { and student } \\
\text { support. }\end{array}$ \\
\hline $\mathrm{I}, \mathrm{C}$ & $\mathrm{K}$ & Medium & $\begin{array}{l}\text { Focused on genre writing in } \\
\text { three genres. Mini Lessons } \\
\text { were provided but a little } \\
\text { disorganized. Scaffolds built } \\
\text { into the lessons and coaching } \\
\text { provided during } 20 \text {-minute } \\
\text { writing time. Taught four } \\
\text { days per week. }\end{array}$ & $\begin{array}{l}\text { There was student } \\
\text { writing on the wall, } \\
\text { and a few anchor } \\
\text { charts. }\end{array}$ & $\begin{array}{l}\text { Students were } \\
\text { growing in their } \\
\text { ability to write } \\
\text { and most had } \\
\text { broken the } \\
\text { print-sound } \\
\text { code. }\end{array}$ & $\begin{array}{l}\text { Teacher liked the } \\
\text { lessons and the } \\
\text { modeling but felt } \\
\text { overwhelmed with } \\
\text { what her students } \\
\text { could not yet do. }\end{array}$ \\
\hline $\mathrm{I}, \mathrm{C}$ & 3 & High & $\begin{array}{l}\text { Focused on genre writing in } \\
\text { three genres. Minilessons } \\
\text { were provided and highly } \\
\text { targeted to specific patterns in } \\
\text { genre writing. Scaffolds built } \\
\text { into the lessons and coaching } \\
\text { provided during unlimited } \\
\text { writing time. Taught four } \\
\text { days per week. }\end{array}$ & $\begin{array}{l}\text { Student writing was } \\
\text { posted and one wall } \\
\text { had anchor charts } \\
\text { that supported } \\
\text { student independent } \\
\text { writing. There was } \\
\text { also a writing center. }\end{array}$ & $\begin{array}{l}\text { Students had } \\
\text { grown } \\
\text { tremendously in } \\
\text { their ability to } \\
\text { write during } \\
\text { science and to } \\
\text { write reports. }\end{array}$ & $\begin{array}{l}\text { Teacher stated she } \\
\text { enjoyed modeling } \\
\text { and how modeling } \\
\text { helps students } \\
\text { know what to do. }\end{array}$ \\
\hline $\mathrm{I}, \mathrm{C}$ & 8 & Medium & $\begin{array}{l}\text { Focused on genre writing in } \\
\text { three genres. Minilessons } \\
\text { were provided with modeling. } \\
\text { Scaffolds built into the } \\
\text { lessons and coaching } \\
\text { provided during } 20 \text {-minute } \\
\text { writing time. Taught four } \\
\text { days per week. }\end{array}$ & $\begin{array}{l}\text { There was not any } \\
\text { student writing } \\
\text { posted and there } \\
\text { were no supports } \\
\text { posted on the walls. }\end{array}$ & $\begin{array}{l}\text { Student writing } \\
\text { had increased, } \\
\text { however the } \\
\text { expectations for } \\
\text { the amount of } \\
\text { student writing } \\
\text { were low. }\end{array}$ & $\begin{array}{l}\text { Teacher enjoyed } \\
\text { the mini lesson } \\
\text { and modeling for } \\
\text { students. }\end{array}$ \\
\hline
\end{tabular}

\section{Copyrights}

Copyright for this article is retained by the author, with first publication rights granted to the journal.

This is an open-access article distributed under the terms and conditions of the Creative Commons Attribution license (http://creativecommons.org/licenses/by/4.0/). 